\title{
BOYCOTTS AND RESTRICTIVE MARKETING ARRANGEMENTS
}

\section{Richard M. Buxbaum*}

$I^{\mathrm{x}}$ $T$ is currently a common if still relatively unheralded practice for a "fired" dealer to bring an antitrust action against his former manufacturer-supplier (and perhaps other dealers), alleging that his termination was the result of a boycott. ${ }^{1}$ Boycottscollective efforts to obtain the exclusion of a party from a marketare illegal per se under section 1 of the Sherman Act. ${ }^{2}$ Thus, questions concerning the justification for the boycott or the significance of the offender's market position do not arise. ${ }^{3}$

A related but even more obscure development in these situations is the growing use of the allegation that the acts complained of constituted an attempt to monopolize a usually unspecified market.4 While attempts to monopolize are less clearly per se offenses, and while the proper definition of the relevant market in such cases is still a matter of debate, ${ }^{5}$ it is likely that only the difficulty of proving a specific intent to monopolize stands in the way of success in most of these cases. ${ }^{6}$ If boycott law or flexible "attempt to monopolize" rules can be applied to the acts of businessmen who dismiss distributors for failing to comply with restrictive marketing arrangements, much of the current debate over substantive standards may be moot. It seems necessary, therefore, to explore both the concept and scope of the prohibition against boycotts, and its proper place in the marketing field. It should then

- Professor of Law, University of Califormia, Berkeley.-Ed.

I should like to thank Professor Thomas E. Kauper of The University of Michigan Law School for his painstaking critique of the manuscript, without, however, imputing to him any responsibility for its shortcomings.

1. Even commentators who are critical of the developing substantive law frequently accept this approach without question. See, e.g., Potvin, Choosing and Dropping Distributors, 26 A.B.A. SEction of ANTITRUST LAW ProceEdings 99 (1964).

2. Klors, Inc. v. Broadway-Hale Stores, 359 U.S. 207 (1959).

3. See Oppenherm, Federal Antixrust laws 661 (2d ed. 1959).

4. See, e.g., Alles Corp. v. Senco Prods., Inc., 329 F.2d 567 (6th Cir. 1964); Bragen v. Hudson County News Co., 321 F.2d 864 (3d Cir. 1963); Englander Motors, Inc. v. Ford Motor Co., 267 F.2d 11 (6th Cir. 1959); A-1 Business Machs. Co. v. Underwood Corp., 216 F. Supp. 36 (E.D. Pa. 1963); Campbell Distrib. Co. v. Jos. Schlitz Brewing Co., 208 F. Supp. 523 (D. Md. 1962).

5. Compare United States v. E. I. duPont de Nemours Co., 351 U.S. 377, 395-96, 423 n.23 (1956), with United States v. Chas. Pfizer \& Co., 245 F. Supp. 737 (E.D.N.Y. 1965). See also Turner, Antitrust Policy and the Gellophane Case, 70 HARv. L. REv. 281, 294 (1956). 1945).

6. See United States v. Aluminum Co. of America, 148 F.2d 416, 431-32 (2d Cir. 
become evident that the boycott concept is itself too vague, and has been too loosely applied, to be useful in judging marketing practices. At the same time, it will be shown that the boycott prohibition is not necessary for condemning those practices found illegal under applicable substantive standards. A similar if less elaborate review of the law on attempts to monopolize should likewise show that problems inherent in the use of the allegation of attempted monopolization in such marketing complaints militate against its acceptance, and that this allegation is also not necessary to condemn practices which are illegal under the developing substantive standards.

Although the foregoing comments do not directly concern the substantive standards of the legitimacy of the various restrictive marketing arrangements whose termination occasions litigation, 7 those standards are at present a matter of such dispute that a brief sketch of the field is in order. The distribution of goods through independent channels has always troubled antitrust policy makers, since the effect of such exclusive arrangements upon competition is ambivalent. On the one hand, competition in the distribution of the particular goods being marketed is restrained, or manufacturers of competing goods are foreclosed from certain distribution channels. On the other hand, the same practices may strengthen competition between the goods being distributed through independent channels and the goods of other producers.

The United States Supreme Court has recently indicated that it is groping for standards to apply to these distribution arrangements; 8 however, its tentative list of criteria is still extremely vague. ${ }^{2}$ The developing standards may vary with the particular practice. There are indications that a territorial restriction differs in legality from a promise not to handle competing goods, ${ }^{10}$ and

7. See, e.g., Day, Exclusive Territorial Arrangements Under the Antitrust LawsA Reappraisal, 40 N.C.L. REv. 223 (1962); Jordan, Exclusive and Restricted Sales Areas Under the Antitrust Laws, 9 U.C.L.A.L. REv. III (1962); Robinson, Restraints on Trade and the Orderly Marketing of Goods, 45 CoRNeLL L.Q. 254 (1960); Stone, Closed Territorial Distribution: An Opening Question in the Sherman Act, 30 U. CHr. L. Rev. 286 (1963).

8. See White Motor Co. v. United States, 372 U.S. 253 (1963). Cases now pending offer an opportunity for further clarification. See United States v. Arnold Schwinn \& Co., 237 F. Supp. 323 (N.D. Ill.), prob. juris. noted, 34 U.S.L. WEEK 3197 (U.S. Dec. 7, 1965); United States v. General Motors Corp., 234 F. Supp. 85 (S.D. Cal. 1964), prob. juris. noted, 380 U.S. 940 (1965). However, the General Motors case is essentially a resale or collective price-fixing situation.

9. See Stewart, Exclusive Franchises and Territorial Confinement of Distributors, 22 A.B.A. Section of Antrtrust Law Proceenings 33 (1963); Panel Discussion on Vertical Arrangements Under the Antitrust Laws, id. at 120, 126-27, 129-31 (1963).

10. Compare White Motor Co. v. United States, 372 U.S. 253 (1963), and Snap-On Tools Corp. v. FTC, 321 F.2d 825 (7th Cir. 1963), with Standard Oil Co. of Cal. v. 
that exclusive requirements contracts are to be treated differently from tie-in arrangements. ${ }^{11}$ More important, the legal standards may vary from well-established economic standards. An economist studying industrial organization judges the tie-in, the promise not to handle competing goods, and the exclusive requirements contract all by their direct preclusive effect upon competitors of the manufacturer in their efforts to sell goods. ${ }^{12}$ The exclusive dealership, the territorial limitation, the customer restriction, and the vertical pricefixing agreement, on the other hand, interest the economist because of their direct effect upon the competitive purchasing opportunities of customers for a particular manufacturer's product. ${ }^{13}$ Although one formal legal distinction corresponds to this economic one-the latter practices essentially fall under section 1 of the Sherman Act, while the former fall under both section 1 of the Sherman Act and section 3 of the Clayton Act-the substantive legal standards currently developing do not seem to fall into line on the basis of that distinction. If any characterization of the developing legal standards is possible, it may be this: Some authorities would adopt objective "share of the market" data as dispositive throughout, ${ }^{14}$ while others would use a test which balances various justifications against the indispensability of the practice for achieving the justified end. ${ }^{15}$ In each camp, however, the other's primary tests seem to be employed as important secondary tests. The foregoing classification does not hint at "hard" or "soft" lines when one gets down

United States, 337 U.S. 293 (1949), and Mytinger \& Casselberry, Inc. v. FTC, 301 F.2d 534 (D.C. Cir. 1962).

11. Compare Tampa Elec. Co. v. Nashville Coal Co., 365 U.S. 320 (1961), with Northern Pac. Ry. v. United States, 356 U.S. 1 (1958), and United States v. Loew's Inc., 371 U.S. 38 (1962). But cf. Atlantic Ref. Co. v. FTC, 381 U.S. 357 (1965).

12. See Bowman, Tying Arrangements and the Leverage Problem, 67 Yale L.J. 19, 25-27 (1957); Burstein, $A$ Theory of Full Line Forcing, 55 Nw. U.L. REv. 62 (1960); Ferguson, Tying Arrangements and Reciprocity: An Economic Analysis, 30 LAw \& CoNTEMP. PROB. 552 (1965); Lockhart \& Sacks, The Relevance of Economic Factors in Determining Whether Exclusive Arrangements Violate Section 3 of the Clayton Act, 65 HARv. L. REv. 913, 942-48 (1952).

13. See Preston, Restrictive Distribution Arrangements: Economic Analysis and Public Policy Standards, 30 LAW \& CONTEMP. Prob. 506 (1965). This is an illustration of the "structure-behavior" interaction which is common in current economic descriptions. See BAIN, INDUSTRIAL Organization (1958).

In the long run, of course, these effects merge. The impact of the first group of practices upon the structure of the supplier market in time will have consequences for the choices open to customers. But economists find it useful to separate these short-range and long-range effects for analysis, and on the whole the decisions seem to be following this approach. But see United States v. Loew's Inc., 371 U.S. 38, 44-45 (1962).

14. See Rahl, Antitrust Policy in Distribution, 104 U. PA. L. REv. 185, 199 (1955).

15. See, e.g., Robinson, Restraints on Trade and the Orderly Marketing of Goods, 45 Cornecu L.Q. 254 (1960); Smith, Vertical Arrangements in Antitrust Law: Exclusive 
to cases. The second group contains writers to whom the necessity of a given practice to achieve the justified goal is often self-evident, ${ }^{10}$ as well as writers who are ingenious at suggesting equally efficient but less restrictive provisions and who therefore condemn the given practice. ${ }^{17}$

It seems clear that the substantive debate is important enough to justify the following effort to clarify the concepts being used in that debate. In any event, I would assert that some debate over substantive standards is still possible, and that "per se" rules have not taken over the entire field of restrictive vertical distribution arrangements. Whether one speaks of "per se" versus "rule of reason" standards in substantive terms, or, more appropriately, sees the rule of reason as a method of inquiry into the degree of specific proof or defense appropriate to a given practice, ${ }^{18}$ some defensive possibilities exist even for such flagrant practices as tie-ins and promises not to handle competing goods. ${ }^{19}$ At the other extreme, formidable proof requirements quite obviously still exist with regard to territorial limitations and exclusive requirements contracts. $^{20}$

\section{Boycotts}

Several types of practices are encompassed by the term "boycott," and therefore some system of classification is required before a proper analysis of such practices can be undertaken. These practices fall into two main groups: collective boycotts and "boycotts" by single entities enjoying a dominant or monopolistic market position.

\section{A. Collective Boycotts}

Generally speaking, an economic boycott requires the cooperation of a party at a different level in the distribution process from

Dealing Arrangements, 22 A.B.A. Section of Antrtrust Law Proceedings 18 (1963). In this general field, Bok, The Tampa Electric Case and the Problem of Exclusive Arrangements Under the Clayton Act, 1961 SuP. CT. REv. 267, 290-319, remains the most ambitious effort to evaluate various justifications and develop from them standards for decision.

16. See, e.g., Robinson, supra note 15; Stewart, Franchise or Protected Territory Distribution, 8 ANTITRUST BulL. 447 (1963).

17. See, e.g., Note, 75 HARv. L. Rev. 795 (1962).

18. See Loevinger, The Rule of Reason in Antitrust Law, 50 VA. L. REv. 23 (1964).

19. In lieu of detailed citations, see Brown Shoe Co. v. United States, 370 U.S. 294, 329-31 (1962).

20. See notes 8-11 supra and accompanying text. See also KAYSEN \& TURNER, ANTITRUsT PoLICY 157-80 (1959). 
that on which the instigators operate. ${ }^{21}$ Even though members of an industry wish to punish or eliminate a certain competitor, they can do so only by inducing the competitor's customers or suppliers to stop dealing with him. This they may do, however, by threatening in turn to stop dealing with the competitor's customers or suppliers. If such coercive action is adopted, it may be difficult to isolate the offensive practice. The cases are surprisingly vague. If the original threat by the initiators is the illegal act, then the stress is upon the means, and the legitimacy of the end is irrelevant. The cases seem to make this the crucial point. The combination-the collective agreement needed to bring the transaction within section 1 of the Sherman Act-is the arrangement between the manufacturers who agree to boycott retailers who will not act in the desired fashion vis-à-vis the competing manufacturer. ${ }^{22}$ Thus the retailers, as well as the competing manufacturer, are the victims. The example may be turned around if it is a group of retailers who wish to punish one of their number; indeed, the latter is the more common case.

As evidenced by the facts in Klor's, Inc. ข. Broadway-Hale Stores, ${ }^{23}$ such a combination may be operative at the responding level as well as at the inducing level. It was alleged that defendant Broadway-Hale objected to price-cutting on several appliance lines by its retail competitor, Klor's, and therefore induced a variety of suppliers (who were also defendants) to cease dealing with Klor's. It is clear that the original interests sought to be protected were those of Broadway-Hale; at least it was Broadway-Hale which allegedly complained of Klor's price-cutting and used the leverage of its purchasing power to persuade its suppliers to boycott Klor's. ${ }^{24}$ If Broadway-Hale had gone to only one supplier

21. This discussion does not deal with fully voluntary boycotts, in which all members on a given level in the competitive process participate in order to achieve common goals. Arrangements of this nature may require an agreement to refuse to deal with certain parties at a different level in the distribution process. See, e.g., Kiefer-Stewart Co. v. Joseph E. Seagram \& Sons, 340 U.S. 211 (1951), where Seagram and Calvert were found to have agreed not to sell liquor to Indiana wholesalers who would not resell below a price ceiling.

22. See Fashion Originators' Guild of America, Inc. v. FTC, 312 U.S. 457 (1941). The combination may be a mixed one including vertically related parties as well. See, e.g., Radiant Burners, Inc. v. Peoples Gas Light \& Coke Co., 364 U.S. 656, 659 (1961). Again, the emphasis is upon the joint action of the inducing parties, and as the following textual discussion will demonstrate, this is the proper approach. For a discussion of the various possible combinations, see Turner, The Definition of Agreement Under the Sherman Act: Conscious Parallelism and Refusal To Deal, 75 HARv. L. REV. $655,685-86$ (1962).

23. 359 U.S. 207 (1959).

24. Id. at 209. 
and persuaded it to discontinue sales to Klor's, the "boycott" might not have been established, even though the effect would have been identical. ${ }^{25}$ On the other hand, if Broadway-Hale and other retailers had concertedly coerced the same supplier, there would have been a collective boycott at the initiating level..$^{28}$

There is often distinguished a type of "boycott," or collective refusal to deal, which is thought to be a price-fixing agreement in disguise. Vertical price-fixing contracts, whereby even a single retailer agrees to resell goods purchased from a supplier at the prices set by the latter, are illegal per se under the rule laid down in Dr. Miles Medical Co. v. John D. Park \& Sons. ${ }^{27}$ This doctrine, which is an exception to current rules governing analogous vertical arrangements (such as territorial divisions and end-customer restrictions), was bound to conflict with notions of the individual trader's right of unilateral refusal to deal. Yet if we ignore non-economic motives for such refusals, ${ }^{28}$ it should be apparent that almost all refusals to deal are a means of achieving or maintaining some vertical control such as price maintenance, customer restrictions, or manufacturer or dealer exclusives.

In the vertical price-maintenance area, boycott notions have been combined with the Dr. Miles per se rule and with newer concepts of "implied conspiracy," so as to negate any realistic possibility that a manufacturer could refuse to deal with a price-cutting distributor. ${ }^{29}$ This result is exemplified by United States $v$. Parke, Davis \& $\mathrm{Co}^{3}{ }^{30}$ which involved a fairly typical effort to police retail

25. Cf. Packard Motor Car Co. v. Webster Motor Car Co., 243 F.2d 418 (D.C. Cir.), cert. denied, 355 U.S. 822 (1957). A rare dictum to the contrary, applying boycott principles to a two-party vertical arrangement, is found in United States v. New York Great Atl. \& Pac. Tea Co., 173 F.2d 79, 83 (7th Cir. 1949). See Note, 51 Gal.rF. I. REv. 608, 618-19 (1963).

26. See Fashion Originators' Guild of America v. FTC, 312 U.S. 457 (1941).

27. 220 U.S. 373 (1911). For the basis of this rule, at least in part, in the dislike of restraints on alienation, see Levi, The Parke, Davis-Colgate Doctrine: The Ban on Resale Price Maintenance, 1960 Sup. Cr. REv. 258, 270-78.

28. I find it puzzling that commentators tend to overemphasize this freedom to refuse to deal for non-economic motives. See, e.g., Rahl, Per Se Rules and Boycolts Under the Sherman Act: Some Reflections on the Klor's Case, 45 VA. L. REv. 1165, 1171 (1959). The two types of motive are adequately distinguishable, and difficulties with nonrestrictive motives, or even with "ethical" motives that have a peripheral restrictive tendency, need not be imported into the field here under discussion. That is an instance where super-fine analysis only confuses the issues.

29. This conclusion is challenged by Fulda, Individual Refusals To Deal: When Does Single Firm Conduct Become Vertical Restraint?, 30 LaW \& ConTEMP. Prob. 590 (1965), but-subject to the discussion in note 54 infra-I do not believe he has refuted the existence of this trend. Compare Kessler \& Stern, Competition, Contract, and Vertical Integration, 69 YALE L.J. 1, 41-42 (1959).

30. 362 U.S. 29 (1960). 
prices by cutting off supplies to mavericks. Certainly the few "special" facts mentioned by the court-inducing wholesalers to stop dealing with offending retailers, and obtaining explicit agreement of the retailers to stop price advertising-would not be unusual components in most market situations.

Although even this decision does not clearly characterize the refusal to deal, the "boycott" conspiracy involved was that between the "web" of distributors who entered into a horizontal agreement to achieve price uniformity at their level. It is possible to see the twoparty vertical agreement between Parke, Davis and a dealer as the operative conspiracy or agreement if the arrangement is successful. ${ }^{31}$ The finding of a conspiracy is hardly possible, however, if the plan fails because one of the two parties involved declines to conspire. ${ }^{32}$ If, on the other hand, the operative conspiracy is that of the retailers to secure price discipline, then violation of the law is practically automatic. The concerted action results either in compliance by or punishment of the offending retailer, and in both cases there is no denying the existence of the conspiracy. In effect, the operative "refusal to deal" in most of the price-fixing cases is not collective, but rather is a responding sanction imposed by the supplier. ${ }^{33}$ There was in Parke, Davis, as in Klor's, an implicit inducing refusal to deal by the retailers, but it was more hidden and did not figure in the court's analysis except to suggest the necessary multiplicity of conspirators. This case development away from the single-party vertical agreement to the collective horizontal or mixed conspiracy eases the search for a unified approach to judging all such restrictions, as does the relaxing of requirements for finding a "conspiracy," which was influenced by the per se illegality of resale price agreements.

31. "Parke Davis created a combination with the retailers and the wholesalers to maintain retail prices ...." Id. at 45. "The product then comes packaged in a competition-free wrapping .... by virtue of concerted action induced by the manufacturer. The manufacturer is thus the organizer of a price-maintenance combination or conspiracy in violation of the Sherman Act." Id. at 47 . See also note 22 supra.

This seems to be the result in the closely analogous case of Simpson v. Union Oil Co. of Cal., 377 U.S. 13 (1964). In Simpson "there was an agreement for resale price maintenance, coercively employed." Id. at 24. (Emphasis added.) The last two words quoted-r-coercively employed"-are properly the subject of speculation. See Handler, Recent Antitrust Developments-1964, 63 Mich. L. REv. 59, 62-65 (1964).

32. Possibly one could characterize the compliant distributor and the manufacturer as conspirators in their effort to bring a rebelling distributor back into the fold. Their lack of success could then be shrugged aside under the decision in United States v. Socony-Vacuum Oil Co., 310 U.S. 150 (1940).

33. Even if the supplier is often cast in the role of the activist, as in Parke, Davis, this only obscures the fact that his decision to maintain a certain retail pricing image is a response to the vagaries of the retail market structure as he finds it, and an attempt to maximize his profit within that framework. Compare text accompanying notes 49-53 infra. 
In summary, "collective refusals to deal," which have been prohibited since the Supreme Court decision in Fashion Originators' Guild of America, Inc. v. FTC, 34 constitute not one but several practices. The initiator may be an individual or a group. In cases where the initiator is acting alone, the responding parties-those wielding the direct club against the maverick - must be multiple.

\section{B. Boycotts by Monopolists}

Boycotts by monopolists also encompass differing practices. The standard example of such conduct may be found in Lorain Journal Co. $v$. United States, ${ }^{35}$ where a monopolist wishing to eliminate a minor competitor threatened to discontinue sales to buyers of advertising space unless they agreed to stop dealing with the competitor. Again, an inducing and a responding refusal to deal were involved, and again, the former arrangement was the important one. The case might have been disposed of by finding a collective conspiratorial response by the advertisers in the Klor's sense or, more accurately, in the sense of an implied conspiracy like that found in Interstate Circuit, Inc. $v$. United States. ${ }^{30}$ Such a disposition was deemed unnecessary, since the initiating party had a dominant market position. Apparently the boycott-initiating act amply satisfied the conduct requirement of the "monopolize" or "attempt to monopolize" language of section 2 of the Sherman Act.

As a general rule, however, the prohibition of a refusal to deal as part of an attempt to monopolize goes far beyond the field of two-level boycotts. One of the older cases, which is often cited to overcome the absence of a collective act at either level of the boycott situation, is Eastman Kodak Co. v. Southern Photo Materials

34. 312 U.S. 457 (1941).

35. 342 U.S. 143 (1951).

36. 306 U.S. 208 (1939). See also United States v. Masonite Corp., 316 U.S. 265 (1942). The "invitation to a common end," which is condemned in these cases, requires the coordinated or simultaneous movement of the invitees into the transaction upon request of the instigator, and thus, strictly speaking, may be too restricted a doctrine to explain Klor's. However, the Court's concern with the coordinated abandonment of price advertising in Parke, Davis is explainable in these terms. For efforts to expand the limits of this doctrine, or perhaps to merge all of these notions into a general doctrine of conspiracy, compare Girardi v. Gates Rubber Co. Sales Div., 325 F.2d 196 (9th Cir. 1963), with Klein v. American Luggage Works, Inc., 323 F.2d 787 (3d Cir. 1963). In any event, it does not appear that the courts are very much concerned with labeling the exact sub-species of the conspiracy doctrine with which they justify a decision, and probably would not stick at the "simultaneous movement" requirement if it ever were an issue in litigation. For an attempt to reconcile these cases, see Fulda, supra note 29 , at 597. 
Co. ${ }^{37}$ In that case the "boycotter" was seeking vertical integration forward into the distribution field, and when its effort to buy out a local distributor of its product failed, it refused to continue supplying the distributor. This conduct was successfully challenged as an illegal refusal to deal, since it was undertaken in furtherance of Eastman Kodak's monopolization of the relevant market. In this context, of course, Southern Photo's complaint was an effort to prevent vertical integration and to freeze an existing distribution framework for a particular product line. Nevertheless, the integration effort was not judged on the same basis as a merger, but rather on almost a "per se" footing. ${ }^{38}$

The antitrust law's feeble grapplings with dual distribution problems are reflected in Eastman Kodak. It is reminiscent of Poller v. Columbia Broadcasting System, Inc., ${ }^{39}$ at least as the latter is described in Mr. Justice Harlan's dissent. Furthermore, the revulsion of the courts against a manufacturer who "steals a march" on independent distributors because of his integrated, "cheaper" structure is obvious here. This attitude is evidenced in some dubious vertical integration cases, ${ }^{40}$ and it is also apparent in attacks on resale price maintenance ${ }^{41}$ and price discrimination ${ }^{42}$ by dual-functioning

37. 273 U.S. 359 (1927). See also United States v. Klearflax Linen Looms, Inc., 63 F. Supp. 32 (D. Minn. 1945).

38. Strictly speaking, where there is an adequate relevant market, Eastman Kodak's method of vertical integration should be a per se violation, but the whole point is that the Court apparently will accept any definition of that market. The foregoing statement may be disputable if applied directly to Eastman Kodak itself, but it very clearly characterizes the use of Eastman Kodak in Poller v. Columbia Broadcasting Sys., Inc., 368 U.S. 464, 468-69 (1962). This result is in contrast to the more rigorous approach to completed monopolies under $\S 2$ of the Clayton Act. See United States v. E. I. duPont de Nemours \& Co., 351 U.S. 377 (1956). Indeed, the Poller decision is similar to the looser approach toward attempts to monopolize, id. at $395 \mathrm{n} .23$ and toward mergers under $\$ 7$ of the Clayton Act, see Brown Shoe Co. v. United States, 370 U.S. 294, 325 (1962).

39. 368 U.S. 464 (1962). For present purposes, it is interesting to note the factual context of the Poller decision. The Columbia Broadcasting System purchased a local station, and thereafter refused to deal further with another competing local station. CBS transferred the network programming from the latter station to its new subsidiary.

40. See, e.g., United States v. New York Great Atl. \& Pac. Tea Co., 173 F.2d 79 (7th Cir. 1949); Reynolds Metals Co. v. FTC, 309 F.2d 223 (D.C. Cir. 1962). See also Adelman, Integration and Antitrust Policy, 63 HARv. L. REv. 27, 53-57 (1949); Adelman, Effective Competition and the Antitrust Laws, 61 HARv. L. REv. 1289, 1312-17 (1948).

41. United States v. McKesson \& Robbins, Inc., 351 U.S. 305 (1956).

42. See Borden Co. v. FTC, 339 F.2d 133 (5th Cir. 1964), cert. granted, 34 U.S.L. WeEK 3117 (U.S. Oct. 12, 1965). See also Klein v. Lionel Corp., 237 F.2d 13 (3d Cir. 1956). Unfortunately, the best discussion of all aspects of dual distribution channels is not available in English. See JACOB-Steinorth, Der Zweigleisige Vertrieb von MARKENWAREN IM DEUTSCHEN UND AMERIRANISCHEN RECHT (1964). A shorter, more thaxrowly based study is Jordan, The Robinson-Patman Act Aspects of Dual Distribution 
manufacturers. The mixture of unfair competition doctrines with antitrust laws has produced an odd blend, but that is a separate story. The practice which has been described herein as a "monopolistic refusal to deal" is only tangentially to be classified as a per se boycott offense. ${ }^{43}$

\section{Boycotts as a Prohibited Means of Enforcing Restrictive Distribution ARRANGements}

This review of the practices which are commonly lumped together under the "boycott" label suggests that the term itself is too loosely and variously used to be appropriate for accurate characterization of the legal status of such activity. In addition, and as the following discussion will demonstrate in greater detail, the per se illegality of most of these boycott situations cannot be appropriately attached to such practices. Indeed, if such labels were appropriate, all restrictive distribution contracts would eventually be illegal, for the refusal to deal as a sanction to obtain or repress certain behavior is a self-evident companion of all restrictive marketing arrangements, or, in other words, of all manufacturers' arrangements in imperfectly competitive markets. ${ }^{44}$

The basic question is this: If a given restrictive distribution arrangement is legitimate in its factual context, can its enforcement be considered illegal once it is characterized as a boycott? A growing number of cases seem to indicate that this question should be answered affirmatively. For example, in McElhenney Co. v. Western Auto Supply ${ }^{45}$ former franchise holders of Western Auto complained of the termination of their franchise, alleging that it occurred because of their refusal to stop selling competing products. A remand to allow amended pleadings that properly alleged a "conspiracy" was granted, the court recognizing the legitimacy of "unilateral refusals to deal" but condemning a restrictive course of

by Brand of Consumer Goods, 50 CoRnenL L.Q. 394 (1965). It is hoped that the Supreme Court's opinion in Borden will stimulate further discussion of these problems, which touch on unfair competition as well as price discrimination.

43. Perhaps these "monopolization" cases are best classified by comparing them to "collective boycott" decisions, which really involve the exercise of market power by members of an association with membership barriers. See note 21 supra. If so, the analogy between Eastman Kodak and Poller and such cases as Associated Press v. Taft. Ingalls Corp., 340 F.2d 753 (6th Cir.), cert. denied, 382 U.S. 820 (1965), and United States v. Insurance Bd. of Cleveland, 188 F. Supp. 949 (N.D. Ohio 1960), should be explored. See also Silver v. New York Stock Exchange, 373 U.S. 341 (1963); Turner, supra note 22 , at 666-67.

44. See Comment, 58 Yale L.J. 1121 (1949).

45. 269 F.2d 332 (4th Cir. 1959). 
dealing between seller and buyer ${ }^{46}$ that might ripen into an implied understanding. The court went on to say that a treble damage action could be based only upon an autonomous violation of the antitrust laws-here section 3 of the Clayton Act. ${ }^{47}$ In testing the pleadings under that section, however, the court merely repeated that the asserted distinction between unilateral and consensual refusals to deal was dispositive of the legality of the practice. ${ }^{48}$ Neither the relevancy of the line of commerce nor the substantiality of the effect upon competition was even broached.

This approach may achieve undue respectability as a result of certain language in Mr. Justice Brennan's concurring opinion in White Motor Co. v. United States. ${ }^{49}$ Seeking guidelines with which to judge territorially protected exclusive-distribution arrangements, he looked first to the circumstances of their genesis. He felt that if these exclusive arrangements were "essentially" the work of a horizontal agreement among dealers rather than an expression of the manufacturer's interests, then they would be illegal. ${ }^{50}$ This is usually not a useful line of inquiry. As an influential student comment $^{51}$ had already pointed out, the manufacturer's own interest in effective distribution often dictates his yielding to dealers' insistence on exclusivity. ${ }^{52}$ Territorial security will be a major demand of any potential distributor-even one acting autonomously -so the prevalence of territorial-security clauses proves nothing. There may be an occasional situation where a joint demand for territorial security by a group of potential distributors achieves for each a position that no individual would have had sufficient leverage to obtain. This rare case can be condemned. The. pressure for such provisions, however, is undoubtedly a factor in most negotiations, and a supplier's stand in the face of that pressure depends upon the bargaining distributor's leverage-the distribution potential he seems to offer the supplier in comparison with other alternatives. ${ }^{.83}$

46. Italics are supplied to call into question the court's preoccupation with the two-party, vertical course of dealing.

47. See 269 F.2d at 337.

48. Id. at $337-38$.

49. 372 U.S. 253, 264 (1963).

50. Id. at 267.

51. Note, 75 HaRv. L. Rev. 795 (1962).

52. "But an approach that attempts to determine which party's interest or initiative is more fully served by the agreement encounters difficulties; for the most significant interests of the manufacturers are themselves framed in terms of the interests of the dealer." Id. at 825. (This note was cited several times in Mr. Justice Brennan's concurring opinion.) But see Turner, supra note 22, at 698-99.

53. This includes other potential distributors with whom a better bargain might 
Such considerations are only subsidiary to the issue that should be the central concern of the law in this field: the degree to which territorial-protection clauses narrow customer choices of alternative offerings of that supplier's product. To concentrate on "conspiracy" would be useless in most situations and, if uncritically extended to what I posit as the "normal" case, would be unduly harsh. Indeed, if a multitude of dealers make the same demand, even if the later ones to do so are influenced by the earlier demands of the others, a conspiracy (actual or implied) is still not made out. At the least, Turner's objection, put forth in a different structural context, to condemning ambiguous conduct which can be characterized as either autonomous or collective behavior is equally applicable in this situation. ${ }^{54}$

Mr. Justice Brennan's concurring opinion in White Motor gives too much weight to these conspiracy concepts and to other nonquantifiable aspects of distribution arrangements. The relative need for the territorial-protection provision to achieve the asserted end is made too important a factor in the evaluation of the legality of the provision..$^{55}$ It is true that Mr. Justice Brennan does not entirely ignore the dealer's local market position and the manufacturer's more general "share of the market" 56 and both approaches are thus available for further development. At present, however, the notion of collective conspiracy in the creation of restrictive

be struck as well as vertically integrated distribution efforts, which might be more favorable despite the initial investment required.

54. See Turner, supra note 22 , at $666,671,683$. Fulda, supra note 29 , sees the problem entirely as one of conspiratorial refusals to deal, and seeks to show-by use of essentially the same group of cases used herein-that the courts (at least sometimes) are reluctant to draw the full consequences from their acceptance of conspiracy allegations, and thus often find for defendants on the merits. Such reluctance is to be expected, but to leave the matter there is to accept a jungle of ill-articulated cases (see $i d$. at $605 \mathrm{n.82}$ ), tortuous distinctions (see id. at 595-97), and impossible dogma (see the discussion of "mere switching of distributors," id. at 597 n.46). Further, it forces use of the "no completed contract" error in Clayton Act $\& 3$ cases (see text accompanying notes 78-85 infra) in order to hold tie-in and exclusive dealing provisions to the same standards as those applied to Sherman Act \& 1 restrictions-a result running counter to the scheme of the section. For an attempt to use a generous conspiracy doctrine to overcome the latter objection, coupled with an uncritical acceptance of the conspiracy theory in the entire restrictive distribution field, see Comment, 64 YALE L.J. 581 (1953). It still seems preferable to attempt a conceptual synthesis of the field.

55. See 372 U.S. at 269-70. For even less appealing discussions, see Snap-On Tools Corp. v. FTC, 321 F.2d 825, 831-32 (7th Cir. 1963); United States v. Arnold, Schwinn \& Co., 237 F. Supp. 323 (N.D. Ill.), prob. juris. noted, 34 U.S.L. WEEK 3197 (U.S. Dec. 7, 1965).

56. See 372 U.S. at 268. Compare Tampa Elec. Co. v. Nashville Coal Co., 365 U.S. 320 (1961); Standard Oil Co. of Cal. v. United States, 337 U.S. 293 (1949). 
distribution arrangements has borne unwelcome fruit in litigation concerning the termination of such arrangements.

Many of the cases which discuss termination of distribution contracts display an uncritical acceptance of the idea that collusion is the key to a finding of illegality. ${ }^{57}$ This is not surprising, since even some older decisions rejected attacks upon terminations of distributorships on the ground that producers are always free to refuse to deal, rather than in terms of a market analysis. ${ }^{58}$ With the shrinking of the refusal-to-deal immunity under the joint effect of Parke, Davis and the implied conspiracy concept, such cases are no longer authoritative, but their method of approach remains to confuse the issue in other termination cases. Thus, even legitimate revisions of distribution patterns may be challenged when such action results in the dismissal of one dealer in order to substitute another or an integrated marketing system..$^{59}$

The aforementioned approach is even less sound in termination situations than in abstract reviews of territorial clauses. A dealer's distributorship may be cancelled because he failed to abide by a restrictive distribution agreement, ${ }^{60}$ and in another case his contract may not be renewed in order to make way for another, better dealer ${ }^{61}$ or to develop a system of vertical integration. ${ }^{62}$ The change

57. See, e.g., Bales v. Kansas City Star Co., 336 F.2d 439 (8th Cir. 1964); Walker Distrib. Co. v. Lucky Lager Brewing Co., 323 F.2d I (9th Cir. 1963); Gorham \& Johnson, Inc. v. Chrysler Corp. 308 F.2d 462 (5th Cir. 1962), cert. denied, 372 U.S. 912 (1963); Moutoux v. Gulling Auto Elec., Inc., 295 F.2d 573 (7th Gir. 1961); Precision Dynamics Corp. v. American Hosp. Supply Corp., 241 F. Supp. 436 (S.D. Gal. 1965); Julius M. Ames Co. v. Bostitch, Inc., 240 F. Supp. 521 (S.D.N.Y. 1965); American Mfrs. Mut. Ins. Co. v. American Broadcasting-Paramount Theatres, Inc., 221 F. Supp. 848 (S.D.N.Y. 1963); Donlan v. Carvel, 209 F. Supp. 829 (D. Md. 1962); Alpha Distrib. Co. of Cal., Inc. v. Jack Daniels Distillery, Lem Motlow Prop., Inc., 207 F. Supp. 136 (N.D. Cal. 1961), aff'd, 304 F.2d 451 (9th Cir. 1962). For other cases dealing with similar allegations of collusion, see Hoffman Motors Corp. v. Alfa Romeo S.p.A., 244 F. Supp. 70 (S.D.N.Y. 1965); Automatic Radio Mfg. Co. v. Ford Motor Co., 242 F. Supp. 852 (D. Mass. 1965); A.B.T. Sightseeing Tours, Inc. v. Gray Line New York Tours Corp., 242 F. Supp. 365 (S.D.N.Y. 1965); C.B.S. Business Equip. Corp. v. Underwood Corp., 240 F. Supp. 413 (S.D.N.Y. 1964); Hutchinson v. American Oil Co., 221 F. Supp. 728 (E.D. Pa. 1963). But see Ace Beer Distribs., Inc. v. Kohn, Inc., 318 F.2d 283 (6th Gir.), cert. denied, 375 U.S. 922 (1963).

58. See Packard Motor Car Co. v. Webster Motor Car Co., 243 F.2d 418 (D.C. Cir. 1957); Schwing Motor Co. v. Hudson Sales Co., 239 F.2d 176 (4th Cir. 1956), cert. denied, 355 U.S. 823 (1957). But see the market analysis explanation of these cases in Mr. Justice Brennan's concurring opinion in White Motor Co. v. United States, 372 U.S. 253, 269 n.8 (1963).

59. See Walker Distrib. Co. v. Lucky Lager Brewing Co., 323 F.2d 1 (9th Cir. 1963). 1959).

60. See, e.g., McElhenney Co. v. Western Auto Supply Co., 269 F.2d 332 (4th Cir.

61. See, e.g., cases cited in notes 58 and 59 supra.

62. See, e.g., Julius M. Ames Co. v. Bostitch, Inc., 240 F. Supp. 521 (S.D.N.Y. 1965); Hutchinson v. American Oil Co., 221 F. Supp. 728 (E.D. Pa. 1963). 
may have been suggested or instigated by a fellow dealer, ${ }^{\text {B }}$ or even by several complaints from fellow dealers. ${ }^{64}$ If, however, the particular restrictive marketing pattern is considered legitimate under applicable standards, these considerations should all be irrelevant. Other dealers may very well object to a fellow dealer's poaching in violation of a territorial provision, but that has nothing to do with the legality of the system.

Only in one special situation would a collective complaint of this nature be relevant. There are cases in which the restrictive provision is introduced into an existing distribution network for the first time after a dealer acts against the expectations of fellow dealers, as, for example, by poaching on their territories. ${ }^{\text {eb }}$ Discussions between the complaining dealers before they call in their supplier may be a more common occurrence in such cases than when a distribution network is first being created. This is clearly a case of initiation of restrictive clauses and, if such discussions occur, can be condemned on the strictest theory of conspiracy, but should not justify similar condemnations where an existing and presumably legal restrictive provision is being disobeyed.

The appeal of conspiracy theories throughout these areas is understandable but meretricious. Admittedly, most of the pressure on suppliers to initiate or enforce price maintenance or territorial exclusivity comes from the "fair" dealers. Moreover, these practices, which particularly concern distributors, rather than competing manufacturers, raise problems that technically deal with section 1 of the Sherman Act rather than section 3 of the Clayton Act. But that should be irrelevant; the applicable standards should emphasize the result of each practice in its economic context rather than the circumstances of its evolution.

The policing of vertical price maintenance seems to be judged purely by the application of boycott principles. ${ }^{68}$ This approach is

63. See, e.g., Ace Beer Distribs., Inc. v. Kohn, Inc., 318 F.2d 283 (6th Cir.), cert. denied, 375 U.S. 922 (1963).

64. See Walker Distrib. Co. v. Lucky Lager Brewing Co., 323 F.2d 1 (9th Cir. 1963). The court considered the factor of multiple complainants to be vital to the case. Id. at 7-8. Compare Mr. Justice Brennan's concurring opinion in White Motor. In fairness to the foregoing opinions, it should be noted that they purport to reject conspiracy counts in instances where a single new distributor persuades the supplier to switch to him and away from a previous distributor. But then there typically follows a search for "multiple" conspiring parties. For a picture of the resulting confusion, see Perryton Wholesale, Inc. v. Pioneer Distrib. Co. of Kan., Inc., 5 CCH TradE REg. REP. If 71605 (10th Gir. 1965).

65. See, e.g., Girardi v. Gates Rubber Co. Sales Div., 325 F.2d 196 (9th Cir. 1963). Compare Kessler \& Stern, supra note 29 , at 82 n.375.

66. See United States v. Parke, Davis \& Co., 362 U.S. 29 (1960). 
acceptable, since agreements to maintain resale prices are illegal per se. ${ }^{67}$ Thus the only problem is to find an "agreement." Indeed, because of the strictness of the foregoing rule, any provision for the maintenance of resale prices is bound to fare harshly in the courts, and the slightest evidence of a collective arrangement will suffice to condemn the practice. ${ }^{68}$ But so long as an entire network of vertical agreements to divide territories or customers ${ }^{69}$ is valid, even though engendered by pressures from the retail level, the manufacturer's insistence that these agreements be honored on pain of non-renewal of dealerships, or termination of existing relationships in order to create other arrangements, should be equally valid.

\section{III. "Attempts To Monopolize” as a Challenge To Marketing ARRANGEMENTS}

A growing number of complaints allege that a termination of a dealer in favor of another dealer, or in favor of vertical integration, is part of an attempt to monopolize local distribution of the supplier's products in violation of section 2 of the Sherman Act. ${ }^{70}$ For

67. See note 27 supra. As an original proposition, this rule can be criticized. Vertical price fixing and vertical exclusive territory arrangements are equally good or bad. Such practices inhibit competition at the distribution level, but only in the one product involved. Manufacturers' business motives for setting up a network of distributors who are bound to sell only at a certain price, and for setting up a network of exclusive territories, are essentially similar. The different approaches of $D r$. Miles and White Motor are therefore anomalous. One practical justification for the differing results may be that suppliers carefully weigh the relative cost of indulging in territorial security, whereas less reflection may accompany price maintenance decisions, since the cost of the latter practice to the supplier is less apparent: See Telser, Why Should Manufacturers Want Fair Trade?, 3 J. LAw \& EcoN. 86 (1960).

68. See note 36 supra. In other words, the only threshold requirement in such cases is the existence of an agreement; indeed, coercion now substitutes for agreement to some undefined extent. See Simpson v. Union Oil Co. of Cal., 377 U.S. 13 (1964); cf. Osborn v. Sinclair Ref. Co., 286 F.2d 832 (4th Cir. 1960), cert. denied, 366 U.S. 963 (1961). For an explanation of this development, see note 86 infra and accompanying text. Compare Sun Oil Co. v. FTC, 350 F.2d 624, 635-36 (7th Cir. 1965), cert. denied, 34 U.S.L. WEEK 3245 (U.S. Jan. 17, 1966).

69. If White Motor represents the substantive law in this area, it may be unrealistic to assume that end-customer restrictions can be valid. See White Motor Co. v. United States, 372 U.S. 253, 272-75 (1963) (Brennan, J., concurring).

70. For some interesting recent efforts to apply this doctrine in ordinary distribution situations, see Continental Ore Co. v. Union Carbide \& Carbon Corp., 370 U.S. 690 (1962); Best Advertising Corp. v. Illinois Bell Tel. Co., 339 F.2d 1009 (7th Cir. 1965); Laundry Equip. Sales Corp. v. Borg-Warner Corp., 334 F.2d 788 (7th Cir. 1964); Bergjans Farm Dairy Co. v. Sanitary Milk Producers, 241 F. Supp. 476, 480 (E.D. Mo. 1965); South Carolina Council of Milk Producers, Inc. v. Newton, 241 F. Supp. 259 (E.D.S.C. 1965); Hutchinson v. American Oil Co., 221 F. Supp. 728 (E.D. Pa. 1963); Deltown Foods, Inc. v. Tropicana Prods., Inc., 219 F. Supp. 887 (S.D.N.Y. 1963); Poster Exch., Inc. v. National Screen Serv. Corp., 198 F. Supp. 557 (N.D. Ga. 1961), aff'd, 305 F.2d 647 (5th Cir. 1962). Compare H. E. Fletcher Co. v. Rock of Ages Corp., 326 F.2d 13 (2d Cir. 1963); A-1 Business Machs. Co. v. Underwood Corp., 216 F. Supp. 36 (E.D. Pa. 1963). 
reasons similar to those advanced against the use of the boycott concept, it would seem that marketing arrangement problems need not and should not-at least not primarily-be resolved through the use of section 2 of the Sherman Act.

The most common point of confusion involves the correct standards for definition of the geographic or product market within which the attempt is alleged to have taken place. Some authorities point to standards as high as those applied in straight monopolization cases, which define the market broadly through conventional economic analysis and thus diminish the relative position, and thereby the vulnerability to attack, of the supplier. ${ }^{71}$ Other authorities seem to have applied less rigorous standards ${ }^{72}$ by adopting an analogy to conspiracy cases, ${ }^{73}$ in which actual power to achieve the desired result is regarded as unnecessary. If the latter standard were accepted for attempt cases, its application to marketing situations would again raise the danger of automatic illegality. Although the additional requirement of a specific intent to monopolize might be an important and appropriate barrier to such results, nevertheless specific intent is generally found in the "viciousness" of the acts constituting the attempt. In marketing cases, the admittedly restrictive and often exclusionary provision being policed or imposed by the manufacturer too readily qualifies for that label.

Some courts are accepting, perhaps too readily, the validity of charges brought under section 2 of the Sherman Act on the basis of an admittedly restrictive provision and an inadequately defined market. ${ }^{74}$ This practice, if accepted, in effect would subvert the examination that should properly be made: application of the appropriate substantive standards to the total restrictive arrangement pattern in its market context. ${ }^{75}$ It is not reasonable to accept a complaint under section 2 of the Sherman Act if the marketing system in question would not be illegal under some other provision such as section 3 of the Clayton Act. Since the Clayton Act is in one

71. For recent arguments for this position which distinguish attempts to monopolize from conspiracies to monopolize, see United States v. Chas. Pfizer \& Co., 245 F. Supp. 737 (E.D.N.Y. 1965); Becker v. Safelite Glass Corp., 244 F. Supp. 625, 637 (D. Kan. 1965). See also A-I Business Machs. Co. v. Underwood Corp., 216 F. Supp. 36 (E.D. Pa. 1963); Englander Motors, Inc. v. Ford Motor Co., 267 F.2d 11 (6th Cir. 1959).

72. See, e.g., Bragen v. Hudson County News Co., 321 F.2d 864 (3d Cir. 1963); Campbell Distrib. Co. v. Jos. Schlitz Brewing Co., 208 F. Supp. 523 (D. Ind. 1962).

73. Occasionally the allegation in these cases is of a conspiracy to monopolize. See, e.g., Moutoux v. Gulling Auto Elec., Inc., 295 F.2d 573 (7th Cir. 1961).

74. See cases cited in note 72 supra.

75. For a proper analysis under $\S 2$ of the Sherman Act of the marketing context, see Alles Corp. v. Senco Prods., Inc., 329 F.2d 567 (6th Cir. 1964). 
sense designed to head off incipient but not yet full-blown violations of the Sherman Act, ${ }^{76}$ such a practice is indefensible in light of the interrelationship of the two statutes. Finally, certain restrictive vertical marketing provisions, such as territorial exclusivity, do not fall under section 3 of the Clayton Act, and therefore must be judged under the Sherman Act. ${ }^{77}$ If these marketing arrangements are being attacked under section 2 of the Sherman Act in order to avoid the conspiracy requirements of section 1, a proper application of these section 1 requirements, as discussed below, would remove the pressure for such allegations. Here too, as in the boycott situations, an objection to the developing practice should be registered.

\section{The Correct Understanding of "Agreement" in Vertical Distribution Situations}

The foregoing discussion has emphasized the need to differentiate the problem of when a practice is illegal from the problem of proving the existence of the practice. It will now be helpful to discuss the latter problem in isolation, and to deal separately with restrictions falling under section 1 of the Sherman Act and under section 3 of the Clayton Act. It may then be possible to relate the "agreement" requirements of these two statutes and to suggest a single, easily applied concept of "agreement" suitable for all restrictive marketing provisions falling under either statute.

The Clayton Act requirement is in one sense the easier to satisfy. All that is needed is a finding that a "condition" has been unilaterally imposed by the supplier. It is not necessary to show assent on the part of the distributor. ${ }^{78}$ Although theoretically a supplier is still free to maintain resale price levels by announcing the terms on which he will deal with distributors, such action is nevertheless not legal in the tie-in or exclusive dealing fields.

\footnotetext{
76. See Brown Shoe Co. v. United States, 370 U.S. 294, 317-18 (1962); Standard Fashion Co. v. Magrane-Houston Co., 258 U.S. 346, 355-57 (1922).

77. See note 88 infra and cases cited in note 8 supra.

78. Specifically, \& 3 of the Clayton Act provides: "Sec. 3. That it shall be unlawful for any person engaged in commerce, in the course of such commerce, to lease or make a sale or contract for sale of goods, wares, merchandise, machinery, supplies or other commodities, whether patented or unpatented, for use, consumption or resale within the United States or any Territory thereof or the District of Columbia or any insular possession or other place under the jurisdiction of the United States, or fix a price charged therefor, or discount from, or rebate upon, such price, on the condition, agreement or understanding that the lessee or purchaser thereof shall not use or deal in the goods, wares, merchandise, machinery, supplies or other commodities of a competitor or competitors of the lessor or seller, where the effect of such lease, sale, or contract for sale or such condition, agreement or understanding may be to substantially lessen competition or tend to create a monopoly in any line of commerce."
} 
There exists, however, another, ostensibly judge-made, hurdle under the Clayton Act. A notion has wormed its way into the field to the effect that only consummated agreements can violate that statute. ${ }^{79}$ According to this rule, mere efforts to obtain agreement, or termination of the relationship for refusal of the dealer to cooperate, supposedly do not suffice for a violation of section 3 of the Clayton Act. ${ }^{80}$ In actual practice, however, most courts seem to ignore this rule. ${ }^{81}$ Whatever its reception, this notion seems unsound, since it confuses substantive standards of legality with questions of remedy. The illegal characteristic of such an arrangement is the pattern, which exists whether or not the particular complaining distributor assented to it or refused to cooperate. If an illegal pattern exists, the complaining distributor need not show he was part of it in order to recover for the harm visited upon him by virtue of the manufacturer's effort to create or maintain it. ${ }^{82}$ Efforts to justify recovery on finespun if reasonable theories of implied conspiracy are not really needed.83 The illegality of the practice in the total context is enough to allow the next step to be that of proving damages, ${ }^{84}$

79. The cases so holding are reviewed and criticized in Turner, The Definition of Agreement Under the Sherman Act: Conscious Parallelism and Refusals To Deal, 75 HARV. L. REv. 655, 692-94 (1962). Much of what follows in the text is either an extension of, or a borrowing from, the Turner discussion. See id. at 695-703. Certainly Turner was concerned with this problem and was critical of the "executed transaction" requirement. I think subsequent cases permit different and perhaps clearer reflection upon the matter. See also Kessler \& Stern, Competition, Contract, and Vertical Integration, 69 YALE L.J. 1, 83-86 (1959).

80. This doctrine is further explained in Barber, Refusals To Deal Under the Federal Antitrust Laws, 103 U. PA. L. REv. 847, $860 \mathrm{n.52}$ (1955), and is criticized as being surmountable under implied conspiracy doctrines, in Comment, 64 YALE L.J. 581 (1953). See the review of cases and comments in Oppenherm, FeDERAL ANTTrRust Laws 716-18 (2d ed. 1959).

81. I do not believe the doctrine is understood or, more to the point, followed by the courts. One example of this, though distinguishable, is given by Turner, supra note 79, at 693 n.53. See also Osborn v. Sinclair Ref. Co., 324 F.2d 566, 574 (4th Cir. 1963); Walker Distrib. Co. v. Lucky Lager Brewing Co., 323 F.2d 1, 7 (9th Cir. 1963); American Mfrs. Mut. Ins. Co. v. American Broadcasting-Paramount Theatres, Inc., 221 F. Supp. 848 (S.D.N.Y. 1963); Albert H. Cayne Equip. Corp. v. Union Asbestos \& Rubber Co., 220 F. Supp. 784 (S.D.N.Y. 1963).

82. It is now reasonably certain that the disadvantaged distributor has standing to recover damages for a violation of $\$ \mathbf{3}$ of the Clayton Act, even though the statute's aim tends more to the protection of competitive suppliers. See Bales v. Kansas City Star Co., 336 F.2d 439 (8th Cir. 1964). See also Tumer, supra note 79, at 693-94 n.54.

83. In other words, proof of the "condition" or "understanding" that the purchaser must refrain from handling non-competing products, for example, was usually less difficult than proof of a conspiracy under the Sherman Act. In the former situation, the success of the manufacturer in keeping dealers in line with his "announced policy" suffices; in the latter case, some (diminishing) attention is still paid to the means used.

84. See Osborn v. Sinclair Ref. Co., 324 F.2d 566, 571-72, 572 n.8 (4th Cir. 1963). In a rare case there may be no proof of a pattern of conduct by the supplier; then, if indeed the arrangement is challengeable at all, there would have to be a showing of a specific (probably vertical) contractual arrangement between the complaining 
at least where there is some relationship between the practice and the plaintiff's losses. ${ }^{85}$

Admittedly, this analysis either permits different results depending upon whether the restrictive provision is judged under section 1 of the Sherman Act or section 3 of the Clayton Act, or it proves too much in that it is somehow also available in cases under section 1 of the Sherman Act despite that section's conspiracy requirements. If either criticism is valid, it would be preferable for the moment to concede the first. The shortcut in Clayton Act situations is based on the fact that the statute leads to, and indeed requires, a finding of illegality only after the entire practice has been reviewed.

In fact, however, the same shortcut is making its way into the cases under section 1 of the Sherman Act, under the misunderstood rubric, "pattern of coercion." 86 Two recent decisions have indicated that the successful imposition of resale price maintenance as a total pattern is on its way to becoming an automatic violation of the statute.87 In other words, the conspiratorial or collective element in section 1 of the Sherman Act is being dispensed with.

distributor and the supplier. See South End Oil Co. v. Texaco, Inc., 237 F. Supp. 650, 654 (N.D. IIl. 1965); Albert H. Cayne Equip. Corp. v. Union Asbestos \& Rubber Co., 220 F. Supp. 784 (S.D.N.Y. 1963). To reemphasize the point: the use of $\S 1$ of the Sherman Act instead of $\S 3$ of the Clayton Act should be unnecessary in the usual case, and unhelpful in the rare case.

It has been suggested that the whole problem under discussion could be resolved from the point of view of damages, by denying recovery unless the private plaintiff showed public injury. See Timberlake, The Public Injury Aspect of Private Treble Damage Actions, 8 ANTrrRusr Bull. 781, 790 (1963). This assumes that public injury and the substantive law of vertical restrictions are one and the same thing, an assumption that has not yet been articulated by the courts. In any event, it does not preclude the flight to "conspiracy" allegations to avoid the public injury (or substantive law) requirement. See also Kessler \& Stern, supra note 79, at 97-98.

85. The relationship between the illegal practice and the plaintiff's harm may occasionally cause difficulties, but viewing the private remedy as a deterrent usually suggests the answer. For example, a supplier may terminate a distribution agreement on the ground that a distributor will not abide by, or accede to, an "illegal" restriction. Damages should be recoverable in such a case. Similarly, the supplier may have been motivated by a desire to enter into a different distribution arrangement which happens to be "illegal," and the illegal aspect might not have been the factor which resulted in the distributor's termination. Nevertheless, damages may well be recoverable. Finally the supplier may have terminated the distributor in order to end an illegal situation; the problem of damages in this case is another matter. They may be recoverable, but not because of the termination.

86. See Osborn v. Sinclair Ref. Co., 286 F.2d 832 (4th Cir. 1960), cert. denied, 366 U.S. 963 (1961). While purporting to require an express agreement in order to establish a conspiracy, the court made the coerciveness of the TBA tie-in there involved the practical equivalent of an "agreement." See the earlier but relevant discussion of "coercion" in Kessler \& Stern, supra note 79, at 105-06 and n.478.

87. See Simpson v. Union Oil Co. of Cal., 377 U.S. 13 (1964); Lessig v. Tidewater Oil Co., 327 F.2d 459 (9th Cir.), cert. denied, 377 U.S. 993 (1964). 
This is not as significant or radical a development as may appear at first glance. Apart from resale price maintenance cases, in which the conspiracy requirement had already become very attenuated, the only situations in which this "pattern" or "pattern of coercion" approach will be interesting are the territorial and customer restriction cases. All others-exclusive dealing and tie-in cases particularly -are handled under section 3 of the Glayton Act, where this nonconspiratorial pattern approach is appropriate in any event. ${ }^{88}$ If the pattern approach is appropriate in the latter situations, then it is equally appropriate for territory and customer restriction arrangements, since their legality or illegality as a matter of substantive law also depends upon the "total picture" review used under section 3 of the Clayton Act. Indeed, to come full circle, the application of this "pattern of coercion" approach to such resale price maintenance cases as Parke, Davis is also desirable. There, too, the real issues are the same, ${ }^{89}$ and the red herring of collective boycott or implied conspiracy can easily be discarded. Where a true conspiracy finding is essential, the "legitimate refusal to deal v. boycott" antithesis may still be significant. Clayton Act cases, however, need no such finding, and the limited group of Sherman Act situations discussed above should likewise need none. "Coercion" is as good a substitute for "contract, conspiracy or combination" as is "invitation to a common end"- -at least in the vertical distribution field. A successful network provides a substitute for the unambiguous horizontal conspiracy. ${ }^{90}$

If the formal objection is made that the "conspiracy" requirement of section 1 of the Sherman Act must be honored explicitly, it is fair to reply that the implied conspiracy doctrines that were decisive in Interstate Circuit and Parke, Davis are flexible enough to include result-oriented descriptions such as "pattern of coercion."01 In sum, if a marketing practice viewed in the entire market context is, abstractly seen, illegal, there should be no need to search for an agreement upon which to base a complaint. If it is not, boycott concepts should not be used to bootstrap the practice into illegality.

88. Some situations which seem to fall within $\S 3$ of the Clayton Act must be brought under $\S 1$ of the Sherman Act for minor reasons of statutory scope. Sec, e.g., Osborn v. Sinclair Ref. Co., 286 F.2d 832 (4th Cir. 1960), cert. denied, 366 U.S. 963 (1961).

89. That is, the interplay between increased inter-brand competition and decreased intra-brand competition is similar. See Julius M. Ames Co. v. Bostitch, Inc., 240 F. Supp. 521 (S.D.N.Y. 1965); Hutchinson v. American Oil Co., 221 F. Supp. 728 (E.D. Pa. 1963).

90. See Turner, supra note 79, at 692 .

91. See also note 36 supra. 